\title{
Pembagian Waris Etnis Madura Terhadap Anak Luar Nikah di Dusun Kebonan Kecamatan Yosowilangun Kabupaten Lumajang
}

\author{
Qurrotul Ainiyah \\ (STAI Al-Falah As-Suniyyah Kencong Jember dan Dosen IAIN Jember, \\ Email: jayaaini@gmail.com) \\ Syarifah Marwiyah \\ (STAI Al-Falah As-Suniyyah Kencong Jember dan Dosen IAIN Jember, \\ Email: syarifahmarwiyah@yahoo.com) \\ Sri Lumatus Sa'adah \\ (STAI Al-Falah As-Suniyyah Kencong Jember dan Dosen IAIN Jember, \\ Email:Sri.lumatus@yahoo.com)
}

\begin{abstract}
Abstrak:
Paper ini menggunakan pendekatan kualitatif dengan jenis penelitian lapangan (field research) dengan memaparkan; Pertama, bagaimana konsep anak luar nikah dan hak warisnya menurut KUH Perdata (Burgerlijk Wetboek), Kompilasi Hukum Islam, dan Yusriprudensi MK? Kedua, Bagaimana kultur etnis Madura di Kebonan Kecamatan yosowilangun kabupaten lumajang atas pembagian hak waris terhadap anak luar nikah?. Hasilnya, Pertama, dalam Kompilasi Hukum Islam dan KUH Perdata (Burgerlijk Wetboek) menjelaskan anak yang lahir dalam pernikahan walaupun tidak tercatatkan adalah anak sah, sedangkan anak hasil hubungan tanpa pernikahan adalah anak zina dan Yusriprudensi MK menegaskan hubungan anak dengan seorang laki-laki sebagai bapak semata-mata karena adanya ikatan perkawinan, akan tetapi dapat juga di dasarkan pembuktian adanya hubungan darah antara anak dengan laki-laki tersebut sebagai bapak. Sedangkan mengenai pengaturan hak waris anak luar nikah, adanya upaya pemerintah dalam pemberian satu bidang kekuasan kehakiman berupa Peradilan Agama yang membawahi konsep hukum kewarisan. Yang senada dengan konsep asas hukum Lex specialis derogat legi generali yaitu asas penafsiran hukum yang menyatakan bahwa hukum yang bersifat khusus (lex specialis) mengesampingkan hukum yang bersifat umum (lex generalis). Kedua, Dalam pembagian kewarisan anak luar nikah masyarakat Kebonan lebih cenderung menggunakan kewarisan kultural, yakni harmonisasi antara hukum perdata dan hukum Islam yang mengalami
\end{abstract}

al-1hkâm Vol.11 No.2 Desember 2016

DOI 10.19105/al-ihkam.v11i2.1018 
misinterpretasi dalam pemahaman kalangan hukum di Pengadilan Agama

\title{
Kata-kata Kunci:
}

Kultur Masyarakat, Kewarisan Anak Luar Nikah, Madura

\begin{abstract}
:
This field research study applies a qualitative approach to explore; First, how the concept of illegitimate children and their right to inheritance according to the Civil Code (Burgerlijk Wetboek), Compilation of Islamic Law and Jurisprudence Court is. Second, How Madura ethnic culture in the District of Kebonan yosowilangun, Lumajang district deal with the division of inheritance to the illegitimate children. This study found that First, in the Compilation of Islamic Law and the Civil Code (Burgerlijk Wetboek), it is explained that a child born of a marriage couple, although he is not registered is a legitimate child, while the child of a relationship without marriage is considered as illegitimate child, and the Jurisprudence Court affirms that the relationship between a child with a man as the father is only due to a marriage bond. However, it can also be based on evidence proving their blood relationship between the child and the man as the father. As for the provision on inheritance rights of an illegitimate child, the government has made efforts in the provision of a field of judicial authorities in the form of Religious Courts which is in charge of the inheritance law. What is in line with the concept of the legal principle of lex specialis derogat legi generali, is the principle of interpretation of the law which states that a special legal (lex specialis) overrides the general law (lex generalis). Second, in the division of inheritance for the illegitimate child, Kebonan people are more likely to use cultural heritage, namely the harmonization of civil law and Islamic law which has been missinterpreted in the understanding of legal circles in the Religious Court
\end{abstract}

Key Words:

Culture of the Society, Inheritance of Illegitimate Children, Madura 


\section{Pendahuluan}

Pasal 1 Undang-undang No.1 Tahun 1974 tentang Perkawinan menjelaskan bahwa perkawinan adalah ikatan lahir batin antara seorang pria dan wanita sebagai suami istri dengan tujuan membentuk keluarga (rumah tangga) yang bahagia dan kekal berdasarkan Ketuhanan Yang Maha Esa. ${ }^{1}$ Bila secara teologis perkawinan merupakan bagian dari ciri normal segala eksistensi, mengapa kemudian seksualitas harus dipandang negatif? Dari sinilah kemudian fiqh memandang perkawinan sebagai salah satu bagian kehidupan agama yang terpenting. Para fuqaha hanya berselisih saat berhadapan dengan pertanyaan di muka: Mana yang lebih penting, menikah atau menyendiri untuk beribadah? "Para ulama," demikian kata al-Ghazālī, "berbeda pendapat tentang keutamaan nikah. Beberapa di antara mereka menekankan keutamaan nikah hingga mereka lebih mengutamakannya ketimbang menyendiri untuk beribadah kepada Allah (al-takhallî li-'ibîdat Allâh); sementara yang lain, walaupun juga menganggap penting nikah masih mengutamakan menyendiri untuk beribadah."2

Qur'ān menekankan pentingnya keluarga inti dan mengecilkan makna penting kelompok-kelompok sosial yang lebih besar seperti suku atau klan. ${ }^{3}$ Hal ini mungkin ditimbulkan oleh kenyataan bahwa masyarakat Arab di masa pra-Islam sangat mengagung-agungkan suku atau klan dan abai pada kesejahteraan dan keadilan di antara anggota suku. Nabi Muhammad sendiri membangun keluarga virilokal ${ }^{4}$ yang kemudian dikenal sebagai bayt al-Nabi dan para anggotanya ahl al-bayt.

Selain itu di dalam al-Qur'ān ada istilah-istilah yang beragam untuk menyebut keluarga; antara lain âl, ahl, bayt, 'ashîrah, dan qurbâ. Istilah-istilah ini bisa berarti sehimpunan orang yang tinggal dalam rumah yang sama atau yang berasal dari garis keturunan yang sama. ${ }^{5}$

\footnotetext{
1 Soesilo dan Pramudji R., Undang-undang RI No. 1 Tahun1974 tentang Perkawinan (T.tp: Rhedbook Publisher, 2008), 461.

2 Abū Hāmid al-Ghazālī, Iḥyā' 'Ulūm al-Dìn, 2: 22.

3 Demikian amatan W. Montgomery Watt, Muhammad at Medina, (Oxford: The Clarendon Press, 1956), 272-289.

4 Ibid., 277, 284.

5 Avner Gil'adi, "Family," dalam Jane Dammen McAuliffe (ed.), Encyclopaedia of the Qur'ān (Leiden: Brill, 2006), 2: 173.
} 
$\hat{A} l$ berarti rumah tangga atau pengikut. ${ }^{6}$ Mengikuti 'Abd al 'Ațī, istilah keluarga dalam Islam dapat didefinisikan sebagai "bentuk hubungan tertentu yang para anggotanya saling berhubungan melalui hubungan yang diatur oleh agama, diterapkan oleh hukum, dan diinternalisasi oleh individu."7 Selain makna dan arti dari perkawinan menjadi lebih dalam karena selain melibatkan kedua keluarga juga lebih berarti untuk melanjutkan keturunan, di mana keturunan merupakan hal penting dari gagasan melaksanakan perkawinan. Kehadiran seorang anak merupakan kebahagiaan dan kesejahteraan bagi seorang ibu maupun keluarganya karena anak merupakan buah perkawinan dan sebagai landasan keturunan. Untuk membentuk keluarga yang bahagia dan sejahtera, maka orang tua membina dan memelihara anaknya dengan cinta-kasih, perhatian yang cukup termasuk pendidikan, kesehatan, dan kecakapan.

Menurut Kitab Undang-undang Hukum Perdata, dengan perkawinan suami istri memperoleh keturunan. Yang dimaksud dengan "keturunan" di sini adalah hubungan darah antara bapak, ibu, dan anak-anaknya. Jadi antara bapak, ibu serta anak terdapat hubungan biologis. Anak-anak yang dilahirkan dari hubungan biologis dan ditumbuhkan sepanjang perkawinan dinamakan anakanak sah (wettige of echte kinderen). ${ }^{8}$ Namun demikian terdapat pula keadaan dimana kehadiran seorang anak dalam suatu keluarga tidak selamanya merupakan suatu kebahagiaan. Hal ini biasanya terjadi apabila seorang wanita yang tidak bersuami melahirkan anak, hal ini merupakan suatu aib bagi keluarganya. Kehadiran seorang anak di luar perkawinanan akan menimbulkan suatu permasalahan yang cukup memprihatinkan baik bagi perempuan yang melahirkan maupun bagi lingkungan masyarakat setempat. Karena akan menimbulkan pertentangan-pertentangan di antara keluarga maupun di lingkungan masyarakat mengenai kedudukan hak dan kewajiban anak tersebut.

Anak yang dilahirkan oleh seorang perempuan, sedangkan perempuan tersebut tidak berada dalam ikatan perkawinan yang sah

6 Edward William Lane, An English-Arabic Lexicon, (Beirut: Librairie du Liban, 1968), 1: 127.

${ }^{7}$ Hammûdah 'Abd al 'Aṭ̂, The Family Structure in Islam, 19.

${ }^{8}$ Rr. Murdiningsih, Peranan Notaris, Tesis, (Jakarta: FH UI, 2009 ), 35 
dengan pria yang menghamilinya dinamakan anak luar nikah. ${ }^{9}$ Berdasarkan pasal 272 KUH Perdata ${ }^{10}$ pengertian anak luar nikah dibagi menjadi dua, yaitu pengertian dalam arti luas dan sempit. Anak luar nikah dalam arti luas meliputi anak zina, anak sumbang,,11 dan anak luar nikah lainnya. Sedangkan anak luar nikah dalam arti sempit adalah anak yang lahir di luar perkawinan yang sah.

Sedangkan di dalam Kompilasi Hukum Islam tidak menentukan secara khusus dan pasti tentang pengelompokan jenis anak, sebagaimana pengelompokan yang terdapat dalam Hukum Perdata. Namun secara implisit, Kompilasi Hukum Islam menyinggung tentang status dan kedudukan anak luar nikah pada pasal 100 dan pasal 186. Demikian pula yang terjadi dimasyarakat Dusun Kebonan Desa Yosowilangun Kidul Kecamatan Yosowilangun Kabupaten Lumajang, pada umumnya anak di luar nikah disebut anak haram, tidak mempunyai hubungan perdata dengan laki-laki yang menghamili ibunya. Kultur masyarakat melihat bahwa anak luar nikah merupakan cela, sehingga lembaga pengakuan sebagaimana dalam hukum perdata dan yang dianjurkan oleh hukum Islam sebaiknya dihindari. Bagi kultur yang terjadi di masyarakat Kebonan, apabila terjadi hamil di luar nikah maka yang penting adanya perkawinan yang sah untuk menutupi aib. Meskipun setelah perkawinan dilaksanakan pengantin pria tidak pernah kembali lagi ke rumah pengantin wanita. Dengan perkawinan anak yang lahir dari wanita hamil tersebut sudah mempunyai ayah secara resmi, sehingga tidak disebut sebagai anak haram atau anak haram jadah yang tentu akan berpengaruh buruk pada si anak. ${ }^{12}$

Menurut Undang-undang Perkawinan Pasal 43 ayat 1, anak yang dilahirkan di luar perkawinan hanya mempunyai hubungan perdata dengan ibunya dan keluarga ibunya.Artinya, si anak tidak mempunyai hubungan hukum dengan ayah biologisnya, baik yang berkenaan dengan pendidikan maupun dalam hal kewarisan.

\footnotetext{
${ }_{9}$ Abdul Manan, Aneka Masalah Hukum Perdata Islam Di Indonesia (Jakarta : Kencana Prenada Media, 2008), 80.

10 Soesilo dan Pramudji R., Kitab Undang-undang Hukum Perdata (T.tp: Rhedbook Publisher, 2008), 62.

11 Anak yang lahir dari seorang ibu yang dilarang kawin menurut Undang-undang dengan lelaki yang membenihkannya, seperti saudara kandung atau sepersusuan.

12 Manan, Aneka Masalah Hukum, 77.
} 
Berpijak pada argumentasi tersebut di atas, peneliti tertarik untuk menyelenggarakan sebuah penelitian di Dusun Kebonan, dimana di daerah tersebut banyak terjadi kasus lahirnya anak di luar nikah, disebabkan pernikahan yang tidak tercatatkan maupun anak luar nikah akibat pemerkosaan, hubungan seks di luar nikah, dan lain sebagainya. Penelitian ini sekaligus menggali tentang kultur masyarakat tersebut terkait pembagian waris terhadap anak luar nikah. Dengan demikian peneliti menyusun sebuah rencana penelitian yang berjudul Kultur Masyarakat Atas Kewarisan Anak Luar Nikah (Studi Pembagian Waris Etnis Madura terhadap Anak Luar Nikah di Dusun Kebonan Kecamatan Yosowilangun Kabupaten Lumajang)

\section{Status Anak Luar Nikah Menurut KUH Perdata, Kompilasi Hukum Islam Dan Yusriprudensi Mahkamah Konstitusi}

Anak luar nikah adalah anak yang dilahirkan oleh seorang perempuan, sedangkan perempuan itu tidak berada dalam ikatan perkawinan yang sah dengan pria yang menyetubuhinya. Sedangkan pengertian di luar nikah adalah hubungan seorang pria dengan seorang wanita yang dapat melahirkan keturunan, sedangkan hubungan mereka tidak dalam ikatan perkawinan yang sah menurut hukum positif dan agama yang dipeluknya. ${ }^{13}$

Pada pasal 862 sampai dengan pasal $873 \mathrm{KUH}$ Perdata adalah mengenai hubungan hukum antara anak luar nikah dengan orang tuanya. Dengan kata "natuurlijk kind" (anak luar nikah); semua anak sah kecuali anak yang dihasilkan dari zina dan anak sumbang. Kelahiran itu sendiri hanya ada hubungan antara ibu dan anak. Tidak ada hubungan dengan laki-laki yang membuahinya. Baru setelah ada pengakuan dari laki-laki tersebut maka kedudukan anak tersebut sebagai anak sah, begitu juga dalam hal kewarisan. Mengenai pengakuan bisa bukti hubungan darah, hubungan kekeluargaan alamiyah ataupun hubungan kekeluargaan keturunan melainkan pengakuannya yang menjadikan sumber hukum antara anak dan orang tua

Dalam praktik hukum perdata pengertian anak luar nikah ada dua macam, yaitu (1) apabila orang tua salah satu atau keduanya

\footnotetext{
${ }^{13}$ Manan, Aneka Masalah Hukum, 80-81.
} 
masih terikat dengan perkawinan lain, kemudian mereka melakukan hubungan seksual dengan wanita atau pria lain yang mengakibatkan hamil dan melahirkan anak, maka anak tersebut dinamakan anak zina, bukan anak luar nikah, (2) apabila orang tua anak di luar nikah itu masih sama-sama bujang, mereka mengadakan hubungan seksual dan hamil serta melahirkan anak, maka anak itu disebut anak luar nikah. Beda keduanya adalah anak zina dapat diakui oleh orang tua biologisnya, sedangkan anak di luar nikah dapat diakui oleh orang tua biologisnya apabila mereka menikah, dalam akta perkawinan dapat dicantumkan pengakuan (erkennen) di pinggir akta perkawinannya. ${ }^{14}$

Sedangkan pada Pasal 28B ayat (1) UUD 1945: "Setiap orang berhak membentuk keluarga dan melanjutkan keturunan melalui perkawinan yang sah". Menurut UUD 1945 perkawinan yang sesuai dengan norma agama yakni jika bergama islam sesuai dengan rukun nikah, maka status pernikahan adalah sah. Tetapi, UU Perkawinan Pasal 2 ayat (2) mengharuskan adanya pencatatan, jika tidak maka anak tersebut dianggap anak luar nikah. Norma hukum yang mengharuskan sebuah perkawinan dicatatkan menurut undangundang berlaku telah mengakibatkan perkawinan yang sah dan sesuai dengan rukun nikah agama islam (norma agama) menjadi tidak sah menurut norma hukum. Hal ini mengakibatkan pernikahan yang sah secara agama tidak mendapatkan kepastian hukum begitu pula dengan anak hasil pernikahan juga tidak mendapat kepastian hukum termasuk di dalamnya tetang kewarisannya.

Adanya ketentuan dalam UU Perkawinan yang menyebabkan ketidak pastian hukum bagi pelaku nikah 'urfi/ sirri, mencerminkan rasa ketidak adilan di masyarakat dan secara obyektif-empiris telah memasung hak konstitusioanal pelaku nikah 'urfi/sirri dalam memperoleh kepastian hukum dan diskriminatif terkait status pernikahan dan kepastian hukum anaknya. Hal ini bertolak belakang dengan tujuan hokum yang mengatur hidup secara damai. ${ }^{15}$

Kompilasi Hukum Islam tidak mendefinisikan secara jelas tentang definisi anak luar nikah. Karena itu untuk mendekatkan

\footnotetext{
14 Ibid, 81.

15 Van Apeldoorn, Pengantar Ilmu hokum, Terjemahan Incleiding tot de Studie van Het Nederlandse Recht oleh Oertarid Sadio, Noordhoff-kalff, Cet. IV, (Jakarta:N.V., 1985),13
} 
pengertian "anak diluar nikah" akan diuraikan pendekatan berdasarkan terminologi yang tertera didalam kitab fiqh. Istilah "anak zina" merupakan istilah yang populer dan melekat dalam kehidupan masyarakat, namun Kompilasi Hukum Islam tidak mengadopsi istilah tersebut untuk dijadikan sebagai istilah khusus didalamnya. Dalam Kompilasi Hukum Islam, kalimat yang mempunyai makna zina adalah "anak yang dilahirkan di luar perkawinan yang sah" sebagaimana yang terdapat pada Pasal 100 Kompilasi Hukum Islam (KHI), yang menyebutkan bahwa "anak yang lahir di luar perkawinan hanya mempunyai hubungan nasab dengan ibunya dan keluarga ibunya".

Hal tersebut bertujuan agar "anak" sebagai hasil hubungan zina, tidak dijadikan sasaran hukuman sosial, celaan masyarakat dan lain sebagainya, dengan menyandangkan dosa besar (berzina) ibu kandungnya dan ayah alami (genetik) anak tersebut kepada dirinya, sekaligus untuk menunjukan identitas Islam tidak mengenal adanya dosa warisan. Untuk lebih mendekatkan makna yang demikian, Pasal 44 ayat (1) UU Nomor 1 Tahun 1974 menyatakan "hanya bilamana ia dapat membuktikan bahwa isterinya telah berzina dan kelahiran anak itu akibat dari perbuatan zina tersebut."

Pendekatan istilah "anak zina" sebagai "anak yang lahir di luar perkawinan yang sah" berbeda dengan pengertian anak zina yang dikenal dalam Hukum Perdata umum, sebab dalam perdata umum, istilah anak zina adalah anak yang dilahirkan dari hubungan dua orang, laki-laki dan perempuan yang bukan suami isteri, dimana salah seorang atau keduanya terikat tali perkawinan dengan orang lain. Karena itu anak diluar nikah yang dimaksud dalam hukum perdata umum adalah anak yang dibenihkan dan dilahirkan diluar perkawinan dan istilah lain yang tidak diartikan sebagai anak zina.

Sedangkan dalam pertimbangan keputusan Majelis hakim Mahkamah kontitusi dalam pengujian Undang-Undang Nomer 1 Tahun 1974 tentang perkawinan hal ini dapat kita lihat dalam kewenangan Mahkamah, berdasarkan pasal 24C ayat (1) UUD 1945 dan pasal 10 ayat (1) huruf a Undang-undang nomer 24 tahun 2003 tentang Mahkamah kontitusi, sedangkan pertimbangan dari kalangan Hakim Mahkamah Kontitusi secara alamiah, tidak mungkin seorang perempuan hamil tanpa terjadi hubungan pertemuan ovum dan spermatozoa baik melalui hubungan seksual maupun dengan cara 
yang lain berdasarkan perkembangan teknologi yang menyebabkan terjadi pembuahan. Oleh karena itu, tidak tepat tidak tepat dan tidak adil manakala hukum menetapkan bahwa anak yang lahir dari suatu kehamilan karena hubungan seksual di luar nikah atau perkawinan hanya memiliki hubungan dengan perempuan tersebut sebagai ibunya. Adalah tidak tepat dan tidak adil pula jika hukum membebaskan laki-laki yang melakukan hubungan seksual yang menyebabkan terjadinya kehamilan dan kelahiran anak tersebut dari tanggung jawabnya sebagai orang bapak dan bersamaan dengan itu hukum meniadakan hak-hak anak terhadap laki-laki tersebut. ${ }^{16}$

Mahkamah Kontitusi juga menegaskan hubungan anak dengan seorang laki-laki sebagai bapak semata-mata karena adanya ikatan perkawinan, akan tetapi dapat juga di dasarkan pembuktian adanya hubungan darah antara anak dengan laki-laki tersebut sebagai bapak. Dengan demikian, terlepas dari soal prosedur/adminstrasi perkawinan anak yang dilahirkan harus mendapat perlindungan hukum. Jika tidak, maka yang dirugikan adalah anak yang di lahirkan di luar nikah atau perkawinan. Padahal anak tersebut tidak berdosa karena kelahirannya di luar kehendaknya. Anak yang dilahirkan tanpa kejelasan status ayahnya siapa, seringkali mendapatkan stigma di tengah-tengah masyarakat. Hukum harus memberi perlindungan dan kepastian hukum yang adil terhadap status seorang yang dilahirkan dan hak-hak yang ada padanya. Meskipun keabsahan perkawinan masih disengketakan. ${ }^{17}$

Karena pasal 43 ayat (1) UU 1/1974 menyatakan : “Anak yang dilahirkan di luar perkawinan hanya mempunyai hubungan perdata dengan ibunya dan keluarga ibunya, harus dibaca "anak yang dilahirkan di luar perkwinan mempunyai hubungan perdata dengan ibunya dan kelaurga ibunya dengan laki-laki sebagai ayahnya yang dapat dibuktikan berdasarkan ilmu pengetahuan dan teknologi dan/ alat bukti lainnya menurut hukum mempunyai hubungan darah, termasuk hubungan perdata dengan keluarga ayahnya."18

Landasan kedua, yang dipakai oleh Mahkamah Kontitusi terhadap pembacaan "tanpa laki-laki sebagai ayahnya" adalah

\footnotetext{
16 Erlina, Jurnal kontitusi, Volume 1, No 1, November 2012, 43.

17 Ibid., 43.

18 Ibid., 44.
} 
bertentangan dengan UUD 1945 secara bersyarat (conditionally unconstitutional) yakni inkonstitusional selama ayat itu dimaknai menghilangkan hubungan perdata dengan laki-laki yang dapat dibuktikan berdasarkan ilmu pengetahuan dan teknologi dan / alat bukti lainnya menurut hukum pempunyai hubungan darah sebgai ayahnya. ${ }^{19}$

Sedangkan alasan yang lain yang dipaparkan oleh Mahkamah Kontitusi adalah alasan yang berbeda (concuring opinion) disampaikan oleh Hakim Kontitusi Maria Farida Indrarti bahwa keberadaan pasal 2 ayat (2) UU 1/1974 menimbulkan ambiguitas bagi pemaknaan pasal 2 ayat (1) UU 1 nomor Tahun 1974 karena pencatatan yang dimaksud oleh pasal 2 ayat (2) Undang-Undang a qua tidak ditegaskan apakah sekedar pencatatan secara adminstratif yang tidak berpengaruh terhadap sah atau tidaknya perkawinan yang telah dilangsungkan menurut Agama atau kepercayaan masing-masing, ataukah pencacatan tersebut berpengaruh terhadap sah atau tidaknya perkawinan yang dilakukan. Keberadaan norma agama dan norma hukum dalam satu peraturan perundang-undangan yang sama, memiliki potensi saling melemahkan bahkan bertentangan seperti pasal 2 ayat (1) yang pada pokoknya menjamin bahwa perkawinan adalah sah jika dilakukan menurut hukum masing-masing agama dan kepercayaan, ternyata menghalangi dan dihalangi oleh keberlakuan pasal 2 ayat (2) yang pada pokoknya jika telah dicatat oleh instansi berwenang atau pegawai pencatatan nikah. ${ }^{20}$

\section{Kewarisan dalam KUH Perdata dan Hukum Islam}

Ada banyak asas dan dasar hukum waris burgerlijk wetboek yang berpengaruh terhadap pembagian warisan. Dengan mengenal dan memahami makna hakiki dari asas-asas dan dasar-dasar tersebut, pembagian harta warisan kepada ahli waris yang berhak besar kemungkinan akan mencapai hasil yang adil. Di antara asas-asas kewarisan tersebut antara lain pertama, hukum yang bersifat mengatur (aanvullend recht). Hukum waris burgerlijk wetboek termasuk dalam lapangan atau bidang hukum perdata. Semua cabang hukum yang termasuk dalam bidang hukum perdata memiliki kesamaan sifat

\footnotetext{
19 Ibid.

20 Ibid., 46.
} 
dasar, antara lain bersifat mengatur dan tidak ada unsur paksaan. Namun untuk hukum waris burgerlijk wetboek, meskipun letaknya dalam hukum perdata, tetapi ternyata di dalamnya terdapat unsur paksaan. Misalnya, ketentuan yang memberikan hak mutlak kepada ahli waris tertentu atas sejumlah tertentu dari harta warisan atau ketentuan yang melarang pewaris sewaktu hidupnya untuk membuat ketetapan terhadap sejumlah tertentu dari hartanya. Misal di masa hidupnya pewaris telah membuat ketetapan seperti menghibahkan sejumlah tertentu dari hartanya yang dilarang itu, maka penerima hibah mempunyai kewajiban hukum untuk mengembalikan harta yang telah dihibahkan tersebut ke dalam harta warisan guna memenuhi hak mutlak ahli waris yang mempunyai hak mutlak. ${ }^{21}$

Kedua, hanya berlaku untuk warganegara Indonesia golongan tertentu. Penggolongan penduduk dan aturan hukumnya masingmasing tersebut juga diakui oleh UU Perkawinan Nasional, yaitu UU No. 1 Tahun 1974 tentang Perkawinan. Menurut KUH Perdata atau burgerlijk wetboek, ada dua cara untuk mendapatkan warisan, yaitu pertama ahli waris menurut ketentuan undang-undang. Kedua, karena ditunjuk dalam surat wasiat (testamen). Cara yang pertama dinamakan mewarisi menurut undang-undang atau "ab intestato", sedangkan cara yang kedua dinamakan mewarisi secara "testamentair".22

Sebenarnya problem pokok yang dihadapi umat Islam pada masa kini, adalah menyangkut upaya formulasi hukum. Kekakuan pikiran-pikiran kaum tradisionalis, telah membuat umat Islam tidak mampu melihat hukum secara dinamis dan terkungkung oleh pandangan ulama masa lalu yang dipandang sakral dan tidak dapat diganggu gugat. Anggapan bahwa hukum Islam bersifat statis dan abadi berkembang di kalangan tradisionalis. Sementara pendapat lain mengatakan bahwa hukum Islam bersifat fleksibel. Artinya hukum Islam dapat beradaptasi dengan perubahan sosial. Pendapat ini mendasarkan pandangannya pada konsep mashlahah (publik interest), universalitas, dan ijtihad. Pendapat semacam ini berkembang di

21 Anisitus Amanat, Membagi Warisan Berdasarkan Pasal-pasal Hukum Perdata BW, (Jakarta: PT Raja Grafindo Persada, 2000), 1-2.

22 M. Idris Ramulyo, Perbandingan Pelaksanaan Hukum Kewarisan Islam Dengan Kewarisan Menurut Undang-undang Hukum Perdata (BW), (Jakarta: Sinar Grafika, 2000), 72-73. 
kalangan kaum reformis muslim, yang dimotori oleh Muhammad Thaha, Fazlur Rahman, dan lain-lain. ${ }^{23}$

Hukum Islam Indonesia masa kini adalah merupakan sebuah label yang diberikan pada ketentuan hukum Islam yang berlaku di Indonesia dan sekaligus menampilkan corak khas ke-Indonesiaan. Kompilasi Hukum Islam meskipun oleh banyak pihak tidak diakui sebagai hukum perundang-undangan, namun pelaksana di Peradilanperadilan Agama telah bersepakat untuk menjadikannya sebagai pedoman dalam berperkara di pengadilan. Dengan demikian Kompilasi Hukum Islam bidang kewarisan telah menjadi buku hukum di lembaga peradilan agama. Jika dahulu hukum kewarisan berada dalam kitab-kitab figh yang tersusun dalam bentuk buku ajaran, maka saat ini, kompilasi tersebut telah tertuang dalam format perundang-undangan. Hal ini dilakukan untuk mempermudah hakim peradilan agama dalam merujuknya. ${ }^{24}$ Apakah dengan demikian hukum kewarisan dari figh mawâris atau farâid telah digantikan oleh Kompilasi Hukum Islam (KHI)? Suatu hal yang dapat dipastikan adalah bahwa hukum kewarisan Islam selama ini yang bernama figh mawâris atau farâid dijadikan salah satu sumber utama dari kompilasi. Sumber lainnya adalah kenyataan yang berlaku di tengah masyarakat yang tertuang dalam yurisprudensi pengadilan agama.

Kompilasi Hukum Islam yang mengatur kewarisan terdiri dari 23 pasal, dari Pasal 171 sampai dengan Pasal 193. Dari pasal demi pasal yang berkenaan dengan ketentuan kewarisan dapat dikatakan bahwa pada umumnya pasal-pasal kewarisan dari KHI, meskipun di sana-sini terdapat perbedaan dengan kitab figh, dapat ditempatkan sebagai hukum kewarisan Islam dalam bentuknya yang baru.

Jika melihat konsep hukum yang ada, adanya hukum Islam atau hukum kewarisan yang masuk dalam kerangka hukum nasional adalah upaya pemerintah dalam memberikan perhatian lebih kepada masyarakat muslim yang menjadi mayoritas masyarakat Indonesia. Maka pemberian satu bidang kekuasan kehakiman berupa peradilan agama yang membawahi konsep hukum kewarisan menjadi penting.

\footnotetext{
${ }^{23}$ Abdul Gafur Anshori, Filsafat Hukum Kewarisan Islam, (UII Press;Yogyakarta, 2005), 7

${ }^{24}$ Amir Syarifuddin, Hukum Kewarisan Islam (Jakarta: Kencana, 2012), 309.
} 
Hal ini senada dengan konsep asas hukum di negara kita yaitu lex specialis derogat lex generali adalah asas penafsiran hukum yang menyatakan bahwa hukum yang bersifat khusus (lex specialis) mengesampingkan hukum yang bersifat umum (lex generalis).

Menurut Bagir Manan dalam bukunya yang berjudul Hukum Positif Indonesia, sebagaimana kami kutip dari artikel yang ditulis A.A. Oka Mahendra berjudul "Harmonisasi Peraturan Perundangundangan", ada beberapa prinsip yang harus diperhatikan dalam asas lex specialis derogat legi generalis, yaitu pertama, Ketentuanketentuan yang didapati dalam aturan hukum umum tetap berlaku, kecuali yang diatur khusus dalam aturan hukum khusus tersebut; kedua, Ketentuan-ketentuan lex specialis harus sederajat dengan ketentuan-ketentuan lex generalis (undang-undang dengan undangundang); ketiga, Ketentuan-ketentuan lex specialis harus berada dalam lingkungan hukum (rezim) yang sama dengan lex generalis. Kitab Undang-Undang Hukum Dagang dan Kitab Undang-Undang Hukum Perdata sama-sama termasuk lingkungan hukum keperdataan. Maka antara hukum perdata dan hukum Islam adalah harmonisasi hanya saja terhadap konsep anak di luar perkawinan mengalami missinterpretasi dalam pemahaman kalangan hukum di pengadilan Agama.

\section{Demografi Etnik Madura di Kebonan}

Kabupaten Lumajang berbatasan dengan kabupaten Probolinggo di sebelah utara dan kabupaten Jember di sebelah timur, Samudera Hindia di selatan dan kabupaten Malang di barat. Yosowilangun adalah nama salah satu kecamatan di kabupaten Lumajang, provinsi Jawa Timur, Indonesia. Kecamatan ini berbatasan langsung dengan kabupaten Jember, memiliki potensi wisata bahari serta keindahan Pantai Wotgalih dan Meleman. Selain itu daerah ini membudidayakan peternakan ikan dan tambak seperti di Meleman yang terdapat tambak udang sebagai penghasilan dari beberapa penduduk. Dan untuk arena olahraga mancing di Yosowilangun banyak terdapat spot-spot bagus untuk memancing di laut. Kecamatan Yosowilangun merupakan salah satu Kecamatan yang ada di Kabupaten Lumajang. Luas Kecamatan Yosowilangun adalah 17 $\mathrm{km} 2$ dengan jumlah penduduk sebesar 60.083 jiwa yang tersebar pada 12 Desa. 
Di sisi lain, dusun Rowosugo yang merupakan dusun terpencil di bagian paling timur kabupaten Lumajang. Di sebelah timur berbatasan langsung dengan sungai Bondoyudo yang merupakan batas kawasan kabupaten Lumajang dan kabupaten Jember, sebelah barat berbatasan dengan desa Tunjung Rejo yang merupakan desa peninggalan Belanda dan dikenal dengan desa Kristen karena penduduknya yang mayoritas beragama Kristen dengan aliran Jawi Wetan, sebelah utara berbatasan dengan dusun Kebonan, dan sebelah selatan berbatasan dengan dusun Celengmati, penduduknya mayoritas berdarah Madura.

Subyek penelitian ini berlokasi di dusun Kebonan yang masuk dalam Desa Yosowilangun Kidul kecamatan Yosowilangun Kabupaten Lumajang. Mengenai luas wilayah dusun Kebonan tidak ada data pasti namun untuk wilayah Yosowilangun Kidul \pm 729.532 Ha. Dengan ketinggian tanah dari permukaan laut $\pm 11 \mathrm{dpl}$. Dengan jumlah kepala keluarga khusus desa Kebonan 165 keluarga dengan mayoritas bersumber pada pertanian.

Di dusun Kebonan Mayoritas penduduknya beragama Islam dan dari suku Madura, yang mana tidak sedikit dari penduduknya yang melakukan pernikahan di bawah umur. Hal demikian itu masih menjadi hal yang lumrah, begitu juga pernikahan lebih dari satu istri atau poligami. Kedua hal tersebut merupakan sebagian dari sebabsebab yang melatar belakangi terjadinya praktek nikah urfi/nikah sirri. Karena Undang-Undang Pernikahan telah menetapkan batasan umur seseorang layak menikah, dan dalam berpoligami pun telah ditetapkan syarat-syarat yang tidak mudah untuk dipenuhi seperti adanya alasan yang memungkinkan seorang suami untuk nikah lagi, adanya persetujuan dari istri dan lain-lain. ${ }^{25}$ Masyarakat menganggap urusan administrasi yang jelimet dan begitu merepotkan bagi mereka untuk melakukan perkawinan yang dilegalkan oleh Negara.

Menjamurnya pernikahan usia dini dan perkawinan poligami di lingkungan etnis Madura masyarakat Kebonan tidak terlepas dari norma- norma sosial yang berlaku pada masyarakat, yaitu segala pengambilan keputusan berada di tangan suami atau laki-laki. Suami dianggap sebagai kepala keluarga yang harus memimpin rumah

25 Kanwil Kemenag Provinsi Jawa timur, UU RI Nomor 1 Tahun 1974 tentang perkawinan dan peraturan pelaksanaanya (Kanwil Kemenag prov. Jawa timur, 2010) 
tangga. Sehingga apa pun yang menjadi keputusannya harus diikuti oleh istri dan keluarga yang lain. Hal ini dilakukan atas dasar penghormatan kepada orang yang lebih tua atau anggapan sebagai kepala rumah tangga. Istilah demikian di kalangan masyarakat Kebonan yang sebagian besar dari etnis Madura, mereka sebut sebagai nilai-nilai "songkan". Nilai songkan terinternalisasi kuat dalam masyarakat Madura. Perasaan songkan bisa disejajarkan dengan makna 'tidak mungkin menolak permintaan orang yang dituakan atau dihormati dalam hal ini adalah orang tua (bappa'-babbu'), guru, dan tokoh masyarakat di lingkungan masyarakat Kebonan.

Ada beberapa faktor kenapa praktik pernikahan di bawah umur sering dilakukan oleh masyarakat Kebonan, yang didorong oleh dua hal yang pertama karna paksaan dari orang tua dan yang kedua karna perempuan itu hamil di luar nikah. Bagi perempuan yang hamil di luar nikah, menurut kebiasaan masyarakat Kebonan memaksa sang laki-laki tersebut untuk menikahi perempuan yang dihamilinya, tetapi ada pula yang tidak sampai terjadi pernikahan karena pihak masyarakat tidak tahu tempat tinggal sang laki-laki. Biasanya itu terjadi karena sang perempuan bekerja di luar daerah dan melakukan seks pra nikah.

Fenomena pernikahan sirrîl'urf dianggap lumrah oleh masyarakat Kebonan yang mayoritas ber-etnis Madura, dikarenakan sebagai one solution agar terhindar dari fitnah dan perbuatan zina. Sebenarnya mereka menyadari akan konsekuensi yang harus dihadapi. Namun karena itu sudah menjadi kultur di masyarakat Kebonan, maka segala penyelesaian tentang persoalan terutama tentang status dan hak anak diselesaikan dengan kebiasaan dan adat masyarakat Kebonan.

“Dari sekitar 165 kepala keluarga, ada sekitar 17 pasang keluarga yang melakukan pernikahan 'urfî/sirrî. Alasannya bermacam-macam; ada yang karena poligami dan ada pula yang karena paksaan orang tua. Walaupun yang menikah secara paksa akhirnya dicatatkan di KUA oleh keluarganya," 26 kata Supa'at, Mudin dusun Kebonan.

26 Supa'at, wawancara, Kebonan, 15 juni 2016. 


\section{Maslahat dan Ilmu Pengetahuan Sebagai Kultur Kewarisan Anak} Luar Nikah Masyarakat Madura di Kebonan

Kultur masyarakat Kebonan yang masih kental dengan tradisi pernikahan di bawah umur mengakibatkan kultur yang secara turun menurun dilakukan oleh generasinya. Ada pula pernikahan yang terjadi tanpa dicatatkan yang mengakibatkan status anak masuk pada pada kategori anak luar nikah. Begitu juga terdapat anak yang dilahirkan oleh seorang perempuan, sedangkan perempuan itu tidak berada dalam ikatan perkawinan yang sah dengan pria yang menyetubuhinya. Hal semacam ini menimbulkan pertanyaan akan bagaimana hukum waris anak luar nikah menurut adat istiadat, terutama yang berkaitan dengan kultur masyarakat Kebonan tersebut?.

Seiring dengan tumbuhnya kesadaran dan semangat untuk mengamalkan ajaran agama di kalangan masyarakat, khususnya di Indonesia, terdapat satu fenomena yang cukup memprihatinkan, yakni masih maraknya sikap mendua (ambivalensi) yang dipraktikkan umat Islam. Hal ini setidaknya terlihat pada sikap dan cara yang mereka tempuh dalam menyelesaikan persoalan keagamaan, khususnya kewarisan. Di satu sisi, masyarakat muslim Indonesia masih menganggap "relevan" segala ketentuan hukum tekstual faraid yang terdapat dalam al Qur'an. Namun di sisi lain, mereka justru meminta dan menjalankan fatwa baru yang dianggap lebih "adil" dalam perspektif struktur dan aspek budaya masyarakat dalam hal pembagian waris. Atau jika langkah tersebut tidak ditempuh, maka mereka akan melakukan tindakan pre-emptive, yakni membagi harta peninggalan warisan dengan cara hibah sebelum orang tua (pewaris) meninggal. 27

Di kalangan masyarakat Kebonan membagi harta peninggalan warisan dengan cara hibah sudah biasa. Proses ini dimulai pada waktu orang tua masih hidup, keluarga mempunyai harta benda yang terdiri dari barang-barang asal suami, barang-barang asal istri serta barang-barang suami istri sepanjang perkawinan. Segala barang tersebut merupakan dasar materiil bagi kehidupan dan akan disediakan untuk kehidupan keturunan dari keluarga itu. Mewaris

\footnotetext{
${ }^{27}$ Munawir Sjadzali,"Reaktualisasi Ajaran Islam", dalam Iqbal Abdur Rauf Saimina (ed), polemic reaktualisasi Ajaran Islam, (Jakarta: Pustaka Panji Mas 1988), 2
} 
menurut anggapan orang Jawa adalah berusaha mengoperkan harta keluarga kepada keturunannya yaitu untuk anak laki-laki maupun perempuan. ${ }^{28}$ Pada umumnya menurut hukum adat anak yang lahir dari perkawinan ayah dan ibunya yang tidak sah, maka tidak berhak sebagai ahli waris dari orang tuanya. Anak yang tidak sah itu hanya mewaris dari ibu atau kerabat ibunya. ${ }^{29}$

Di daerah Jawa anak yang lahir di luar perkawinan yang sah adalah anak kowar, anak ini hanya dapat mewaris dari ibunya atau keluarga ibunya. Namun demikian apabila kemudian ibunya setelah anak itu lahir kemudian kawin dengan lelaki yang membenih anak tersebut dan anak itu tinggal bersama ayah kandungnya itu, si anak mendapat mewaris dari bapaknya. ${ }^{30}$ Menurut hukum adat di Jawa yang bersifat parental bahwa kewajiban untuk membiayai penghidupan dan pendidikan seorang anak yang belum dewasa tidak hanya dibebankan pada ayah anak tersebut, akan tetapi kewajiban itu juga ditugaskan kepada ibunya. Apabila salah satu dari orang tuanya tidak menepati kewajibannya, hal itu dapat dituntut mengenai biaya selama anak tersebut masih belum dewasa. ${ }^{31}$ Seorang anak yang lahir diluar perkawinan, menurut hukum adat waris di Jawa hanya menjadi waris di dalam harta peninggalan ibunya serta di dalam harta peninggalan keluarga dari pihak ibu. Seorang anak tersebut menurut hukum dianggap tidak mempunyai bapak. Terhadap hubungannya dengan ibu, maka tidak ada perbedaan anak yang sah dengan anak diluar perkawinan. ${ }^{32}$

Sedangkan dalam hukum kewarisan Islam dipresentasikan dalam teks-teks yang rinci, sistematis, konkrit, dan realistis. Kerincian pemaparan teks tentang kewarisan, berimplikasi pada keyakinan bahwa hukum kewarisan Islam tidak dapat berubah, dan menolak segala ide pembaharuan. Hal ini terlihat dari teks kitab-kitab fikih klasik, terutama yang ditulis oleh Imam empat mazhab, yang di dalamnya dijelaskan tentang ayat kewarisan itu merupakan hukum yang qath'î baik dari segi tsubût (ketetapan) maupun dalâlah (penunjukannya). Pembagian harta kepada ahli waris harus sesuai

\footnotetext{
28 Soepomo, Bab-bab tentang hukum adat, (Jakarta:Pradnya Paramitha, 1987) , 79

29 Ibid, 234

30 Ibid, 88

31 Putusan Makamah Agung, tanggal 3-9-1958 Reg No. 216 K/SIP/1958

32 Soepomo, Bab-bab Tentang Hukum, 85.
} 
dengan petunjuk dalam al Qur'an tentang al-furûd al-muqaddarât (bagian yang telah ditentukan yang diterima ahli waris). ${ }^{33}$

Secara teoritis, kewarisan diartikan sebagai suatu fenomena sosiologis, berkaitan dengan seperangkat aturan mengenai proses dan ketentuan-ketentuan peralihan hak dari seseorang yang telah meninggal dunia kepada orang yang masih hidup (ahli waris). Yang berkembang dan berubah sesuai dengan perubahan dan perkembangan masyarakat. Di masa sekarang khususnya di Jawa, jarang sekali dijumpai pelaksanaan hukum Islam, khususnya hukum kewarisan yang berdasarkan fiqh klasik atau farâid. Ini dikarenakan, sebelum Islam masuk di Indonesia, di Jawa sudah berkembang tradisi Hindu dan adat Jawa yang mengakar sangat kuat di masyarakat, sehingga yang bisa dilakukan oleh umat Islam sekarang adalah menginterpretasikan al Qur'an guna memahami pesan Allah. Dalam menginterpretasikan pesan Allah dalam al Qur'an, seseorang dipengaruhi oleh pengalaman pribadi serta sosial budaya di sekelilingnya.

Berbicara tentang interpretasi teks keagamaan (Al Qur'an), agama dan budaya merupakan dua unsur penting dalam masyarakat yang saling mempengaruhi. Ketika ajaran agama masuk dalam satu komunitas yang berbudaya, akan terjadi tarik menarik antara kepentingan agama di satu sisi, dan kepentingan budaya di sisi lain. Pada saat yang sama, dalam menerjemahkan konsep-konsep langitnya ke bumi, Islam mempunyai karakter dinamis, elastis, dan akomodatif dengan budaya lokal, selama tidak bertentangan dengan prinsip Islam itu sendiri. Permasalahannya terletak pada tata cara dan teknis pelaksanaan. Inilah yang diistilahkan oleh Gus Dur dengan "Pribumisasi Islam".34

Proses adaptasi antara ajaran Islam (wahyu) dengan kondisi masyarakat, dipicu oleh semangat pengikutnya yang meyakini bahwa agama Islam sebagai "shâlih li kulli zaman wa makân", (baik di semua zaman dan tempat). Dengan demikian Islam akan senantiasa dihadirkan, dan diajak bersentuhan dengan keanekaragaman

33 Wahbah al Zuhaili, al Figh al Islam wa Adillatuhu, Jilid 10, (Beirut, Dar al fikr, 2005) 747

34 Abdurrahman Wahid, Pribumisasi Islam, dalam Muntaha Azhari dan abdul Mun'in (ed), Islam Indonesia Menatap Masa Depan, (Jakarta: P3M,1989) , 92 
konteks. Fakta yang tidak bisa terbantahkan, bahwa kehadiran Islam dalam setiap konteks, tidak pernah nihil dari muatan-muatan lokal yang mendahului kehadiran Islam. Dalam ungkapan yang lebih vulgar, Islam tidak datang ke suatu tempat dan suatu masa yang hampa akan budaya. Atas dasar inilah, pemikiran akulturasi Islam dengan budaya lokal, dan relasi ajaran agama (hukum Islam) dengan nilai-nilai lokal muncul di wilayah nusantara ini. Sebagai contoh akulturasi hukum Islam dengan budaya lokal adalah proses pelaksanaan hukum kewarisan Islam yang dilakukan keluarga kraton Yogyakarta. ${ }^{35}$

Fenomena untuk melaksanakan ajaran agama, khususnya hukum kewarisan Islam yang berbasis adat (kultural), tidak hanya

35 Menurut hasil penelitian yang dilakukan oleh Rumawi Eswe bahwa sejak Sultan Hamengku Buwono I sampai Sultan Hamengku Buwono IX, keluarga kraton memiliki pola kewarisan yang sama. Pola itu adalah berdasarkan ajaran Islam dan adat keraton atau budaya Jawa. Pola pelaksanaan kewarisan di keraton Ngayogyakarto Hadiningrat, sangat dipengaruhi oleh kebudayaan Islam dan adat jawa, sehingga pembagiannya pun selalu sesuai dengan nilai-nilai kebudayaan Islam, walaupun terkadang ada juga yang masih berdasar adat kejawen. Dalam konteks ini, hubungan kewarisan Islam dengan hukum kewarisan kesultanan Ngayogyakarto, telah terjadi konvergensi unsur-unsur kewarisan. Hukum kewarisan Islam swargi kesultanan Ngayogyakarto telah berhasil menyatukan hukum kewarisan Islam, dengan hukum kewarisan budaya Jawa. Hal - hal yang diadopsi dari sistem kewarisan Islam meliputi; pertama, dalam hukum Islam istri atau janda tidak mempengaruhi waktu pelaksanaan pembagian harta warisan. Sedangkan adat jawa, harta warisan tidak dibagikan selama janda atau istri masih hidup; Kedua, dalam hukum Islam, pembagian harta warisan dengan sistem dua banding satu untuk lakilaki dan perempuan. Sedangkan adat Jawa, anak laki-laki atau perempuan mendapatkan harta warisan yang sama dan; ketiga, dalam Islam seorang istri atau janda memperoleh bagian tertentu, yaitu seperdelapan bagian harta warisan. Sedangkan dalam kebudayaan Jawa, istri atau janda berhak atas seluruh harta warisan suaminya.

Adapun unsur-unsur yang diambil dari adat Jawa adalah klasifikasi harta berdasar harta sultan dan kesultanan. Harta sultan itu adalah harta yang bisa dibagikan ke seluruh ahli waris. Sedang harta kesultanan adalah harta yang istimewa, merupakan kategori harta produktif yang hanya diberikan kepada ahli waris yang tertua, biasanya anak pertama untuk kepentingan keluarga. Dalam pembagian kewarisan di Keraton Ngayogjakarto, ada unsur yang disesuaikan dengan hukum Islam dan adat Jawa yaitu adopsi ahli waris pengganti. Sedang unsur yang tidak disesuaikan dengan Hukum Islam dan adat Jawa adalah tidak adanya klasifikasi harta berdasarkan hubungan perkawinan (harta bersama, harta gono-gini). Inilah yang menjadi ciri khas dalam pelaksanaan pembagian harta warisan di kesultanan Ngayogjakarto. 
terjadi pada lingkungan masyarakat kraton Yogyakarta, akan tetapi hal ini juga dilaksanakan masyarakat yang tinggal di lingkungan masyarakat Kebonan. Dari observasi di masyarakat Kebonan Lumajang, diperoleh data tentang kecenderungan masyarakat untuk melaksanakan hukum kewarisan Islam kultural. Sebuah contoh dari keluarga Ali Ridwan ${ }^{36}$ adalah orang tua yang tidak mempunyai anak dari perkawinan yang dicatatkan, tetapi mempunyai tiga anak luar nikah (nikah urfî/sirrî) dari istri yang lain, maka anak luar nikah akan mendapat warisan dari keluarga bapak biologisnya.

Dalam pembagian harta warisan, bapak tersebut lebih memilih menggunakan cara pembagian sebagai berikut: sebelum meninggal dunia, Ridwan telah membagi harta warisan yang berupa tanah, kepada tiga orang putra-putrinya, dengan menggunakan perbandingan dua berbanding satu. Namun, dalam harta yang lain misalnya tentang toko, rumah, serta mobil, serta beberapa sawah hasil kerja berdua dengan istri pertama langsung diserahkan kepada istri pertama dan istri kedua diwarisi sebuah mobil dan rumah yang ditinggali saat ini. Putra-putri Ridwan tersebut bisa menguasai (memiliki) harta yang sudah dibagi tersebut, setelah Ridwan meninggal dunia. Dengan menyandarkan pada kemaslahatan, bapak Ridwan tersebut telah membagi waris dengan cara tersebut. Menurut keterangannya, dengan membagi waris dengan cara seperti itu kerukunan dan ketentraman keluarga dapat diciptakan.

Dalam hubungan kekerabatan baik antara ayah biologisnya dengan anak luar nikah (nikah urfî/sirrî) dengan keluarga ayah biologisnya cukup pada pengakuan bahwa memang misalnya pria A menikahi ibu anak tersebut, karena masyarakat juga tidak menganggap motivasi menghindari petaka sehingga melahirkan anak luar nikah (nikah urfísirrî) tersebut sebagai perbuatan yang harus dicela dan dikutuk, dan anak tersebut dapat saja secara bebas bergaul dengan keluarga dari ayah biologisnya, bahkan kekerabatannya dapat menjadi lebih erat. Status dari penikahan tersebut adalah sah dan mempunyai hukum tetap (inkracht van gewijsde) sesuai dengan ketentuan pasal 2 ayat (1) UU perkawinan yang menyatakan:" Perkawinan adalah sah, apabila dilakukan menurut hukum masingmasing agama dan kepercayaan itu". Sedangkan pasal $250 \mathrm{KUH}$

36Ali Ridwan, Wawancara, Kebonan ,15 Juni 2016 
Perdata menentukan bahwa tiap-tiap anak yang dilahirkan atau ditumbuhkan sepanjang perkawinan, memperoleh si suami sebagai bapaknya.

Berdasarkan kedua ketentuan diatas, keabsahan suatu perkawinan sangat menentukan kedudukan hukum dari anak-anak, itu berarti ketiga anak dari Ali Ridwan yang dilahirkan dan tumbuh sepanjang perkawinan yang sah menurut agama, memperoleh si suami sebagai bapaknya dan berhak menerima pengasuhan, pendidikan, warisan dan segala sesuatu yang berkaitan dengan hakhak anak.

Fenomena lain terjadi pada peristiwa seperti diceritakan oleh Kiai Syafa'at ${ }^{37}$ modhin atau imamuddin dusun Kebonan. Ia bercerita tentang seseorang yang mempunyai anak dari proses yang tidak absah. Orang tersebut tetap mengakui anak luar kawin tersebut dan menikahi ibu dari anak tersebut setelah usia kandungan 6 bulan. Anak tersebut mendapat perlakuan sama termasuk dalam pembagian waris seperti anak-anaknya yang sah. Ada pula anak luar nikah tanpa perkawinan. Anak luar kawin status anak tersebut menurut Kiai Syafa'at hanya dalam perwalian ibu kandungnya. Keluarga ibu kandungnya menerimanya tanpa membeda-bedakan dengan cucucucu atau anak-anak dari lainnya. Keluarga wanita atau ibu dari anak luar kawin tidak memaksa berlangsungnya perkawinan secara sah kepada pria atau ayah biologisnya, dikarenakan ayah biologisnya tidak mudah dihubungi oleh masyarakat setempat. Menurut kultur masyarakat kebonan, anak ini disebut anak zina. ${ }^{38}$

Dalam kasus-kasus terdahulu terdapat masalah tentang waris anak luar kawin dan telah dikuatkan dalam putusan pengadilan. Dalam hal ini menurut Putusan Pengadilan Negeri Purworejo, tanggal 6 Oktober 1937 dikatakan bahwa : "Anak luar kawin menurut hukum adat tetap berhak atas harta warisan yang ditinggalkan oleh keluarga ibunya sendiri.Tetapi hak waris anak luar kawin itu terbatas pada harta warisan keluarga bapak biologisnya yang berasal dari harta pencaharian bukan harta pusaka", sebagaimana hal tersebut dikuatkan dalam Putusan Makamah Agung Republik Indonesia tanggal 24 Mei 1958 no 82 K/SIP/1957 yang menyatakan : "Anak luar

${ }^{37}$ Syafa'at, Wawancara, Kebonan, 15 Juni 2016

38 Wahyu Afandi, Aneka Putusan Pengadilan, Alumni Bandung, 1984, 289. 
kawin tidak berhak mewarisi barang-barang pusaka, barang-barang ini kembali kepada waris keturunan darah yang sah", Kemudian putusan Makamah Agung tanggal 18 Maret 1959 yang menyatakan : "Menurut hukum adat yang berlaku di Jawa Tengah, anak luar kawin hanya diperkenankan mewaris harta gono gini dari keluarga bapak biologisnya, sedangkan harta pusaka (barang asal) anak luar kawin tidak berhak mewarisinya."39

Dengan demikian kedudukan anak luar kawin menurut hukum adat Jawa pada umumnya yaitu hak anak luar kawin terbatas pada harta pencaharian (gono gini) yang diperoleh sendiri keluarga bapak biologisnya maupun ibunya. Sedangkan terhadap harta pusaka yang diterima bapak biologisnya anak luar kawin tidak berhak mewarisinya, dan harta pusaka tersebut merupakan hak waris dari saudara anak sah atau anak luar kawin dari keluarga bapak biologisnya, apabila ia tidak mempunyai anak sah. Hukum adat di Jawa yang bersifat parental juga berlaku di dusun Kebonan desa Yosowilangun Kidul kecamatan Yosowilangun Kabupaten Lumajang.

Pada kasus yang lain terjadi pada Abdul Aziz yang kebetulan mempunyai tiga orang istri, istri pertama menikah secara sah dalam catatan Negara dan dua istri lainnya menikah secara 'urfì/sirrî. Dalam praktek pembagian warisnya, Aziz lebih memilih menggunakan cara membagi rata kepada putra putrinya. Pembagian ini baru dilaksanakan setelah istri pertama Aziz meninggal dunia. Hal ini berdasarkan hibah dari Aziz kepada putra putrinya, sebelum meninggal dunia. Sebagai konsekuensi dari hibah tersebut, putra putri dari Abdul Aziz telah dibuatkan rumah bagi mereka yang sudah berkeluarga. Sedangkan hasil usaha misalnya tanah pertanian, perkebunan, dan lain-lain, digunakan untuk membiayai mereka yang masih sekolah disamping untuk keperluan bersama dalam keluarga. Kebetulan seluruh putra putri Abdul Aziz berjumlah 7 orang empat dari istri yang dinikahi sah secara negara dan tiga lainnya dari istri yang dinikahi secara sirrî. Menurut keterangan dari beberapa putra putri Abdul Aziz, pembagian waris dengan jalan seperti ini, akan

39 Abdul Aziz, Wawancara, Kebonan 16 Juni 2016 
mudah untuk mendapatkan rasa ketentraman dan menegakkan persatuan dalam keluarga. 40

Dari beberapa praktek pelaksanaan pembagian warisan yang telah dilakukan beberapa masyarakat Kebonan, dapat diambil benang merah bahwa pelaksanakan sistem kewarisan Islam yang dikompromikan dengan budaya, tidak lain hanyalah untuk merealisasikan kemaslahatan dan keadilan dalam kehidupan manusia. Masyarakat Kebonan lebih cenderung menggunakan kewarisan kultural, yakni kewarisan yang dikompromikan dengan adat.

Atho' Mudzhar menyatakan bahwa Hukum Islam pada kenyataannya, tidak resistan dari pengaruh-pengaruh sosial yang melingkupi perkembangannya. Perubahan-perubahan yang terjadi dalam dataran substantif hukum Islam di berbagai belahan dunia Islam, menjadi penguat dari fakta bahwa Hukum Islam pada dasarnya, merupakan hasil dari interaksi antara para ulama dan faktor-faktor sosial yang ada di sekitarnya. ${ }^{41}$

Tentang terwujudnya nilai kemaslahatan dalam pelaksanaan hukum waris Islam berbasis budaya/kultural bahwa maṣlahah merupakan kata kunci dalam upaya merumuskan secara filosofis, kaitan teks wahyu dengan realitas konteks kehidupan umat beragama sehari-hari. Secara etimologis, mașlaḥah mempunyai makna identik dengan manfaat yaitu keuntungan, kenikmatan, kegembiraan atau segala upaya yang dapat mendatangkan hal itu. ${ }^{42}$ Dan ajaran agama apabila sudah turun kedalam ranah konstruksi mental para individu pemeluknya, akan sangat berpeluang untuk mengejawantah dalam wajah yang tidak tunggal. Kesadaran ini kemudian dapat mendorong umat Islam untuk selalu mengambil sikap yang bijak terhadap semua keyakinan, pandangan dan tindakan dalam mengamalkan ajaran Islam. Kesadaran seperti ini juga penting dalam kerangka pengembangan lingkungan sosial umat, dimana pluralitas keagamaan diterima sebagai suatu kelaziman bahkan keniscayaaan.

\footnotetext{
40 Atho' Muzhar, Socisl History Approach To Islamic Law, Jurnal al Jami'ah IAIN Sunan Kalijaga Yogyakarta, No 61.

41 Said Ramadhân al Buthî, Dlawâbith al Mashlahah, (Beirut: Muassasah al risalah, tt), 27.
} 
Selain itu pendekatan dengan hasil mahkamah Kontutusi yang menyatakan Mahkamah Kontitusi juga menegaskan hubungan anak dengan seorang laki-laki sebagai bapak semata-mata karena adanya ikatan perkawinan, akan tetapi dapat juga di dasarkan pembuktian adanya hubungan darah antara anak dengan laki-laki tersebut sebagai bapak. Dengan demikian, terlepas dari soal prosedur/adminstrasi perkawinan anak yang di lahirkan harus mendapat perlindungan hukum. Jika tidak, maka yang dirugikan adalah anak yang di lahirkan di luar nikah atau perkawinan. Padahal anak tersebut tidak berdosa karena kelahirannya di luar kehendaknya. Anak yang dilahirkan tanpa kejelasan status ayahnya siapa, seringkali mendapatkan stigma di tengah-tengah masyarakat. Hukum harus memberi perlindungan dan kepastian hukum yang adil terhadap status seorang yang dilahirkan dan hak-hak yang ada padanya. Meskipun kebasahan perkawinan masih disengketakan. ${ }^{43}$

\section{Kesimpulan}

Dalam KUH Perdata dan Kompilasi Hukum Islam tidak mendefinisikan secara jelas anak luar nikah. Secara umum disebutkan anak yang lahir dalam pernikahan walaupun tidak tercatatkan adalah anak sah, sedangkan anak hasil hubungan tanpa pernikahan adalah anak zina. Yusriprudensi Mahkamah Konstitusi menegaskan hubungan anak dengan seorang laki-laki sebagai bapak semata-mata karena adanya ikatan perkawinan, akan tetapi dapat juga di dasarkan pembuktian adanya hubungan darah antara anak dengan laki-laki tersebut sebagai bapak.

Mengenai kewarisan, dalam KUH Perdata atau Burgerlijk Wetboek, ada dua cara untuk mendapatkan warisan, yaitu pertama; Ahli waris menurut ketentuan undang-undang atau mewarisi menurut undang-undang atau "ab intestato". Kedua, karena ditunjuk dalam surat wasiat (testamen) atau mewarisi secara "testamentair". Sementara Mahkamah Kontitusi juga menegaskan hubungan anak dengan seorang laki-laki sebagai bapak semata-mata karena adanya ikatan perkawinan, akan tetapi dapat juga didasarkan pembuktian adanya hubungan darah antara anak dengan laki-laki tersebut sebagai bapak. Dengan demikian, terlepas dari soal prosedur/adminstrasi

43 Ibid., 43. 
perkawinan anak yang di lahirkan harus mendapat perlindungan hukum.

Dalam pembagian kewarisan anak luar nikah masyarakat Kebonan lebih cenderung menggunakan kewarisan kultural, yakni kewarisan yang dikompromikan antara kemaslahatan dan pembuktian ilmu pengetahuan. Dikaitkan dengan keputusan Mahkamah Konstitusi, maka diakuinya anak luar kawin (hasil biologis) sebagai anak yang sah berarti akan mempunyai hubungan waris dengan bapak biologisnya. Dengan syarat dapat dibuktikan berdasarkan ilmu pengetahuan (tes DNA).

\section{DAFTAR PUSTAKA}

'Abd al 'Ațī, Hammûdah, The Family Structure in Islam, T.p :T.th

Amanat, Anisitus, Membagi Warisan Berdasarkan Pasal-pasal Hukum Perdata BW, Jakarta: PT Raja Grafindo Persada, 2000

Amatan W. Montgomery Watt, Muhammad at Medina. Oxford: The Clarendon Press, 1956

Apeldoorn, Van, Pengantar Ilmu hukum, Terjemahan Incleiding Tot de Studie Van Het Nederlandse Recht oleh Oertarid Sadio, Noordhoff-kalff, Cet. IV, Jakarta: N.V, 1985

Ghazālī al-, Abū Hāāid, Ihyyā' 'Ulūm al-Dìn, T.p: Tt.

Gafur Anshori, Abdul, Filsafat Hukum Kewarisan Islam, UII Press: Yogyakarta, 2005

Gil'adi, Avner, "Family," dalam Jane Dammen McAuliffe (ed.), Encyclopaedia of the Qur'ān. Leiden: Brill, 2006.

Idris Ramulyo, M., Perbandingan Pelaksanaan Hukum Kewarisan Islam Dengan Kewarisan Menurut Undang-undang Hukum Perdata (BW), Jakarta: Sinar Grafika, 2000

Kanwil Kemenag Prov. Jawa Timur, UU RI Nomor I Tahun 1974 tentang perkawinan dan peraturan pelaksanaanya, Surabaya: KANWIL KEMENAG PROV. Jawa Timur, 2010

Manan, Abdul, Aneka Masalah Hukum Perdata Islam Di Indonesia, Jakarta: Kencana Prenada Media, 2008

Murdiningsih, Rr., Peranan Notaris, Tesis, Jakarta: FH UI, 2009

Soesilo dan Pramudji R., Undang-undang RI No. 1 Tahun1974 tentang Perkawinan, T.tp: Rhedbook Publisher, 2008 
2008,Kitab Undang-undang Hukum Perdata.T.tp:

Rhedbook Publisher, 2008

Supranto, J., Metode Riset: Aplikasinya Dalam Pemasaran, Jakarta: Rineka Cipta, 2003

Syarifuddin, Amir, Hukum Kewarisan Islam.Jakarta: Kencana, 2012.

Wahid, Abdurrahman, Pribumisasi Islam, dalam Muntaha Azhari dan abdul Mun'in (Ed.), Islam Indonesia Menatap Masa Depan. Jakarta: P3M, 1989

William Lane, Edward, An English-Arabic Lexicon. Beirut: Librairie du Liban, 1968

Soepomo, Bab-bab tentang Hukum Adat, Jakarta: Pradnya Paramita, 1994

Soemitro, Irma Setyowati, Aspek Hukum Perlindungan Anak, Bumi Aksara, Jakarta, 1990.

Hadikusuma, Hilman, Hukum Kekerabatan Anak, Jakarta: PT. Citra Aditya Bakti, 1987.

Haar, Ter, Asas-asas dan Susunan Hukum Adat (Soebakti Poesponoto Terjemahan) Jakarta: Pradnya Paramita, 1994

Oemarsalim, Dasar-dasar hukum waris diIndonesia, Rineka Cipta, 1991

Sudiyat, Imam, Hukum Adat Sketsa Adat, Yogyakarta: Liberty, 1990.

Wahyu Afandi, Aneka Putusan Pengadilan, Alumni Bandung,1984 